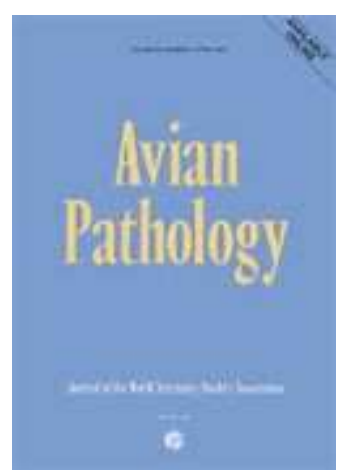

\title{
Evaluation of Newcastle disease virus immunoassays for waterfowl using a monoclonal antibody specific for the duck immunoglobulin light chain
}

\begin{tabular}{|c|c|}
\hline Journal: & Avian Pathology \\
\hline Manuscript ID: & CAVP-2007-0150.R1 \\
\hline Manuscript Type: & Original Research Paper \\
\hline $\begin{array}{r}\text { Date Submitted by the } \\
\text { Author: }\end{array}$ & 09-Jan-2008 \\
\hline Complete List of Authors: & $\begin{array}{l}\text { Kothlow, Sonja; University of Munich, Institute for Animal } \\
\text { Physiology } \\
\text { Häuslaigner, Rafaela; Federal Research Institute for Animal Health, } \\
\text { Institute of Diagnostic Virology; University of Munich, Clinic for } \\
\text { birds } \\
\text { Kaspers, Bernd; University of Munich, Institute for Animal } \\
\text { Physiology } \\
\text { Grund, Christian; Friedrich-Loeffler-Institut, Federal Research } \\
\text { Institute for Animal Health, Institute of Diagnostic Virology; } \\
\text { University of Munich, Clinic for birds }\end{array}$ \\
\hline Keywords: & Newcastle disease, waterfowl, duck, immunoassays \\
\hline
\end{tabular}

\section{SCHOLARONE Manuscripts}


Sonja Kothlow ${ }^{1}$, Rafaela Häuslaigner ${ }^{23}$, Bernd Kaspers ${ }^{1}$ Christian Grund ${ }^{23^{*}}$

${ }_{2}^{1}$ Institute for Animal Physiology, University of Munich, Veterinärstrasse 13, D-80539

Munich, Germany, ${ }^{2}$ Klinik für Vögel, University of Munich, Sonnenstrasse 18, 85764

Munich, Germany, ${ }^{3}$ present address: Institute of Diagnostic Virology, Friedrich-Loeffler-

Institut, Federal Research Institute for Animal Health, Südufer 10, 17493 Greifswald - Insel

Riems, Germany,

*corresponding author

Phone: +49-38351-7 196

FAX: $\quad+49-38351-7226$

E-mail: Christian.Grund@fli.bund.de

Running title: Waterfowl immunoassays

Figure 2 to be in colour in printed version (free of charge)

Received: 22 September 2007

.
Formatted: Font: Times New

Formatted: Right

Formatted: Font: Times New

Roman, 14 pt, Not Bold, Complex

Script Font: 14 pt

Formatted: Left

Formatted: Font: Times New

Formatted: Left

Deleted: Kothlow ${ }^{A}$

Deleted: B C

Formatted: Font: Times New

Formatted: Font: Times New

Deleted: Kaspers $^{\mathrm{A}}$

Formatted: Font: Times New

Deleted: ${ }^{\text {B C }}$

Formatted: Font: Times New

Deleted: ${ }^{A}$ Institute

Formatted: Level 1, After: 0 pt, Space Before: $12 \mathrm{pt}$, Tabs: Not at $127.6 \mathrm{pt}$

Formatted: Font: Times New

Deleted:

Deleted: ${ }^{\mathrm{B}}$ Klinik

Formatted: Font: Times New

Deleted: II

${ }^{\mathrm{C}}$ present

Formatted: Font: Times New Roman, English U.K.

Formatted: Font: Times New

Formatted: Font: Times New
Deleted: Keywords: duck, waterfowl, immunoglobulin

Formatted: Font: Times New

Deleted: $\mathrm{e}$

Deleted: s, immunoassays, Newcastle disease virus II

Formatted: Font: Times New Roman, Italic

Formatted: Font: Times New

Formatted: Font: Times New

Deleted: CAVP-2007-0150.R1

Deleted: CAVP20070150-3

Deleted: CAVP20070150 
Evaluation of Newcastle disease virus immunoassays for waterfowl using a $\underline{\text { monoclonal antibody specific for the duck immunoglobulin light chain }}$

\section{Sonja Kothlow ${ }^{1}$, Rafaela Häuslaigner ${ }^{23}$, Bernd Kaspers ${ }^{1}$, Christian Grund ${ }^{23^{*}}$}

\section{Abstract}

In this study a monoclonal antibody (mab 14A3) was tested for its reactivity against serum immunoglobulin Y ( $\operatorname{IgY}$ ) of several waterfowl species and subsequently for its applicability as antispecies antibody in common immunoassays. Western blot (WB) analyses demonstrated its broad cross reactivity with the serum IgY light chain of different duck species (Muscovy Duck $=$ Cairina moschata, Mallard $=$ Anas platyrhynchos, White-winged Wood Duck $=$ Asarcornis scutulatus, Common Pintail = Dafila acuta) . Reactivity was also evident with IgY of two swan species $($ Mute Swan $=$ Cygnus olor, Black-necked Swan $=$ Sthenelides melanocoryphus) and two goose species (Domestic Goose $=$ Anser anser var. domestica, Redbreasted Goose $=$ Rufibrenta ruficollis). Applying the mab for Newcastle disease virus (NDV, avian paramyxovirus serotype 1 , APMV-1) test systems, its functionality within indirect immunoassays was evaluated. Using APMV-1 positive sera of domestic geese and Muscovy ducks, mab 14A3 facilitated specific staining of APMV-1-infected cells in an immunofluorescence (IF) test. In addition, it proved to be functional in an indirect enzymelinked immunosorbent assay (ELISA) and a WB assay. Thus, the analysed mab represents an attractive and versatile reagent that offers the opportunity to develop serological tests for waterfowl, allowing a high sample throughput using the ELISA technique or the fine analysis of humoral immune responses using the WB.
Formatted: Font: Times New Roman, German Germany Formatted: Body Text, Line spacing: single

Formatted: Font: Times New
Deleted: -

Deleted: d
Deleted: $\mathbb{\Upsilon}$

Deleted: CAVP-2007-0150.R1

Deleted: CAVP20070150-3

Deleted: CAVP20070150 


\section{Introduction}

$\triangle$

In comparison to the situation in chickens or mammals, efficient indirect test-systems for the diagnosis of important bacterial and viral infections in waterfowl that correspond with current economical and public health demands, are not yet sufficiently established and commercially available.

This fact conflicts with a rising importance of serological surveillance in waterfowl. Among the bacterial pathogens, Salmonella is an example in this context that is harboured by wild as well as domestic aquatic birds (Refsum et al.,2002). Commercially kept waterfowl, especially under extensive rearing conditions, can further attract a number of viral infections with economical impact, like reo-, herpes- and parvoviruses, which have to be monitored and diagnosed (Hess et al., 2004; Bernius, 1997). Of particular concern for the poultry industry are infections with viruses that are transmissible to gallinaceous birds, such as Newcastle disease viruses (NDV, avian paramyxovirus serotype 1, APMV-1) and avian influenza viruses (AIV) (Campitelli et al.,2 2004; Takakuwa et al..21998). Beyond this, waterfowl also represent a reservoir of pathogens for humans (Reed et al.,2003). Therefore, regular screening tests are of high importance in the prevention and combat of diseases that represent a threat on economy or human health.

\section{Expectations are that, in addition to high sensitivity and specificity, serological tests} have to achieve speed, simplicity and low cost. Automation of the techı evaluation, as well as the compatibility with large sample numbers are further demands (Murphy ${ }_{2} 1999{ }_{i}$ O'Beirne 1992). Tests used as methods of choice in former times such as the haemagglutination inhibition test (HI test) or the agar gel precipitation test (AGP) are, at least in the first steps of diagnosis, being more and more displaced by faster, automated tests such as the ELISA. In contrast to the situation in chickens and turkeys, where suitable indirect ELISA-test kits have been established (Slaght et al. 1978. Marquart et al. 1980) and are now

Formatted: Indent: First line: 35.4

Deleted: only one candidate to name

\begin{tabular}{|c|}
\hline Deleted: , \\
\hline Deleted: furthermore \\
\hline Deleted: fowl-like \\
\hline Deleted: like \\
\hline Deleted: , \\
\hline Deleted: s \\
\hline $\begin{array}{l}\text { Comment [DA1]: I suggest you } \\
\text { delete this sentence - what you have } \\
\text { written isn't strictly true and a prpoer } \\
\text { explanation would be too lengthy. }\end{array}$ \\
\hline Deleted: As \\
\hline $\begin{array}{l}\text { Deleted: we have seen in the case of } \\
\text { avian influenza, these bird species bear } \\
\text { the risk to favour the emergence of new } \\
\text { highly pathogenic AIVs by mutations or } \\
\text { genetic reassortments. }\end{array}$ \\
\hline Formatted: Font: Times New \\
\hline Deleted: An actual expectation \\
\hline Deleted: is \\
\hline Deleted: accomplish \\
\hline $\begin{array}{l}\text { Deleted: , next to high sensitivity and } \\
\text { specificity, }\end{array}$ \\
\hline Deleted: also \\
\hline Deleted: of \\
\hline Deleted: high \\
\hline Deleted: , \\
\hline Deleted: As \\
\hline Deleted: commonly used tests \\
\hline Deleted: like \\
\hline Deleted: - \\
\hline Deleted: like \\
\hline Deleted: early \\
\hline Deleted: , \\
\hline Deleted: CAVP-2007-0150.R1 \\
\hline Deleted: CAVP20070150-3 \\
\hline Deleted: CAVP20070150 \\
\hline
\end{tabular}


widely used and commercially available, diagnostics in waterfowl still rely on the standard tests, or at the best on competitive ELISA tests. Efforts to develop suitable tools, such as antispecies antibodies for waterfowl, lagged significantly behind the situation in galliform species. Recently, we have developed a range of new monoclonal antibodies reactive with leucocyte cell surface antigens of the duck including a monoclonal antibody (14A3) reactive with the duck immunoglobulin light chain (Kothlow et al., 2005). Here we further evaluate the cross reactivity of mab $14 \mathrm{~A} 3$ with serum immunoglobulins (IgY) of different waterfowl species, as well as its applicability in common serological test-systems to detect APMV1positive reactants.

\section{Materials and Methods}$$
\text { 政 }
$$

Production of monoclonal antibodies. Mab 14A3 was obtained after immunisation of Balb/c mice with $100 \mu \mathrm{g}$ of purified duck IgY emulsified in Freund's complete adjuvant, followed by three booster immunisations in Freund's incomplete adjuvant. Fusions were performed as described (Kothlow et al., 2005) and positive hybridomas were identified by ELISA (Kothlow et $a l, 2005)$ and WB.

Sera. To test the cross reactivity of mab 14A3, field sera from the eight different waterfowl species specified in Figure 1 and chicken serum, were obtained. APMV-1 positive waterfowl sera were derived from immunised adult Muscovy ducks (Cairina moschata) and adult domestic geese (Anser anser var. domestica) that received a two-fold chicken dose of an

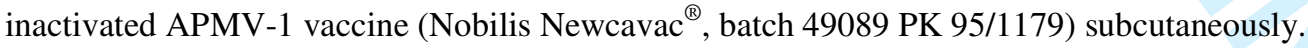
Sera obtained before immunisation and at the indicated time points after vaccination were stored at $-20^{\circ} \mathrm{C}$.
Deleted: broadly

Deleted: previous

Deleted: like

Deleted: have

Formatted: Font: Times New Roman, Not Highlight

Formatted: Font: Times New

Deleted: lacked

\section{Deleted: -}

Formatted: Font: Times New

\begin{tabular}{|l|}
\hline Deleted: - \\
\hline Deleted: - \\
\hline Deleted: of \\
\hline Deleted: as well as a \\
\hline
\end{tabular}

Deleted: the

Deleted: CAVP-2007-0150.R1

Deleted: CAVP20070150-3

Deleted: CAVP20070150 


\section{Western blot analysis to determine the cross-reactivity of mab 14A3. Serum} immunoglobulins (Igs) were separated by $10 \%$ glycine-sodium dodecyl sulfatepolyacrylamide gel electrophoresis (glycine-SDS-PAGE) under denaturing conditions, following standard procedures (Laemmli, 1970) and subsequently transferred to a nitrocellulose membrane (Amersham Biosciences) by semi-dry blotting. Membranes were blocked for 60 minutes with $2 \% \mathrm{w} / \mathrm{v}$ skim milk in phosphate-buffered saline (PBS; pH 7 4 ) containing $01 \%$ Tween 20 , before probing with mab $14 \mathrm{~A} 3$ cell culture supernatant at a dilution of 1:100 in Tris-buffered saline (50 mM Tris, $\mathrm{pH} 7,5$ ), containing $0_{k} 1 \%$ Tween20 (TBST-buffer) plus $3 \% \mathrm{w} / \mathrm{v}$ skim milk. Incubation took place over night at $4^{\circ} \mathrm{C}$ under agitation. Membranes were washed three times for five minutes in TBST-buffer and then covered for 30 minutes with horseradish peroxidase conjugated goat-anti-mouse Ig specific polyclonal antibodies (Sigma), at a dilution of 1:5000 with $3 \%$ skim milk in TBST-buffer. Incubation was performed at room temperature on a shaker. After three further washing steps, membranes were finally incubated for five minutes with a horseradish peroxidase substrate (ECL plus Western Blotting Detection System, Amersham Biosciences) and reaction was visualised by autoradiography on a medical x-ray film (AGFA Curix HT $1.000 \mathrm{G}+$ ).

Indirect immunofluorescence test. Virus was grown on chicken embryo liver cells, prepared from tendayold embryonated SPF fowls' eggs, according to standard procedures (Mayr, 1974) and cultured on microscope slides with removable cups (Sonic Seal Slide Wells, Nunc). After their adherence, cells were infected with APMV-1 strain La_Sota. With the appearance of visible cytopathic effects, approximately 16 hours later, cells were fixed with formalin $(3,7 \%$ in PBS; 2 x 10 min). Formalin was removed and cells were treated with Triton (1\% in PBS; 1 $\mathrm{x}$ shortly and $1 \mathrm{x}$ for 30 minutes). Thereafter, slides were blocked for one hour with $2 \% \mathrm{v} / \mathrm{v}$ foetal calf serum in PBS (blocking buffer). Test-serum was added at a dilution of 1:50 in

\begin{tabular}{l} 
Deleted: \\
Deleted: \\
\hline Deleted: -chicken
\end{tabular}

Deleted: , 
blocking buffer, for an incubation time of 30 minutes, followed by three 5-minute washes with PBS containing $0.1 \%$ Tween 20 . Then, cups were incubated for 30 minutes with mab 14A3 cell culture supernatant (1:10 in blocking buffer) and again washed three times. FITCconjugated sheep anti-mouse-IgG (Sigma) (1:50 in blocking buffer) was added to each well for 30 minutes, also followed by three washing steps. Finally, cups were removed and the slides were covered with SHANDON-Mounting Medium (Thermo Electron Corporation) and a cover slip. Analysis was carried out using a leica fluorescence microscope and images were taken with the help of a microscope camera (Leica).

Enzyme-linked immunosorbent assay. The ELISA was performed in Polysorp Immuno Plates (Nunc). To permit binding of the antigen, plates were incubated over night at room temperature with $50 \mu 1$ purified antigen of APMV-1 strain La Sota, diluted in bicarbonate buffer $\left(42 \mathrm{~g} \mathrm{NaHCO}_{3} / \mathrm{lin}\right.$ Aqua bidest, $\left.\mathrm{pH} 9,6\right)$. The next day, plates were washed three times in washing buffer (PBS plus $0,025 \%$ Tween20) and blocked for 60 minutes with blocking buffer ( $2 \%$ skim milk in washing buffer). Two-fold dilutions of the test sera were done in blocking buffer (beginning with 1:50) and $50 \mu 1$ transferred in duplicate to the antigen coated wells. Following an incubation period of 30 minutes and three subsequent washing steps, $50 \mu 1$ mab $14 \mathrm{~A} 3$ were added to each well (1:10 in blocking buffer). 30 minutes later, plates were washed again and incubated with horseradish peroxidase conjugated goat-antimouse Ig specific polyclonal antibodies (Sigma) (1:250 in blocking buffer, 50 $\mu 1 /$ well). After 30 minutes and following another washing procedure, $100 \mu \mathrm{l}$ of the substrate, orthophenylendiamindihydrochloride (Sigma), were added to each well at a concentration of $1 \mathrm{mg}$ per $\mathrm{ml}$ in citrate-buffer plus hydrogen peroxide $\left(0_{\mathrm{s}} 05 \mathrm{M} \mathrm{Na}\right.$-Citrate $\left.\mathrm{pH} 4 ; 0,15 \% \mathrm{H}_{2} \mathrm{O}_{2}\right)$. After ten minutes in darkness the reaction was stopped with $50 \mu 12 \mathrm{M}$ sulphuric acid in aqua bidest. Optical density was measured by an ELISA-reader (MR 5000 Dynatech Laboratories), using a test filter with an absorbtion wavelength of $490 \mathrm{~nm}$. Titres were determined by defining the
Deleted: ,

Deleted:

Deleted:

\section{Deleted: ,}

Deleted: ,

Deleted: ,

Deleted: ,

Deleted: CAVP-2007-0150.R1

Deleted: CAVP20070150-3

Deleted: CAVP20070150 
cut off as the mean OD-value of the 1:200 dilution of the sera taken at the day of immunisation (background noise) plus the twofold standard deviation.

Haemagglutination inhibition test. The haemagglutination inhibition test (HI test) was

Deleted: -

Comment [DA2]: Both here and in the list ths is not referredto correctly

Deleted: -manual

Deleted: Chapter 2.1.15).

Formatted: Font: Times New

Deleted: ,

Deleted: -

Western blot analysis using mab 14A3 as secondary antibody. APMV-1 antigens were subjected to glycine-SDS-PAGE, blotted on nitrocellulose membranes and blocked for 60 minutes as described above. Test sera were pre-incubated for one hour with allantoic fluid, to diminish unspecific reactivity, centrifuged for $10 \mathrm{~min}$ at $8000 \mathrm{rpm}$ and then brought to a final dilution of 1:1000 with $3 \%$ skimmed milk in TBST-buffer. Membrane-strips were then incubated over night with the diluted test sera at $4^{\circ} \mathrm{C}$, on a shaker. After three 5-minute washes with TBST-buffer, mab 14A3 cell culture supernatant was added at a dilution of 1:100 in TBST-buffer, containing $3 \% \mathrm{w} / \mathrm{V}$ skimmed milk. The following steps correspond with the WB-procedure described above.

\section{Results}

To evaluate possible cross reactivities of mab $14 \mathrm{~A} 3$ with serum Ig Y of different waterfowl species, sera from two goose, two swan and four duck species as well as a chicken serum were tested by WB analysis, using mab $14 \mathrm{~A} 3$ as a probe. In the positive control sera of a domestic goose and a Muscovy duck clear reactivity, at a position identical with that indicating the immunoglobulin light chain in a preceding study of Kothlow et al. (2005), was

Formatted: Font: Times New Formatted: Normal, Line spacing: single

Deleted: -

Deleted: muscovy

Deleted: reactivitiy

Deleted: CAVP-2007-0150.R1

Deleted: CAVP20070150-3

Deleted: CAVP20070150 
visible. All sera of six further waterfowl species also showed this kind of typical band, whereas no specific reaction was noted with the chicken serum (Figure 1). Strongest bands were observed with the light chain of the two swan species from the Subfamily Anserinae (Mute Swan = Cygnus olor and Black-necked Swan = Sthenelides melanocoryphus $),$ as well as with that of the Mallard (Anas platyrhynchos) and the Common Pintail (Dafila acuta) belonging to the Tribus Anatini in the Subfamily Anatinae. Moderate bands were visible with samples from the Muscovy Duck (Cairina moschata) and the White-winged Wood Duck (Asarcornis scutulatus) from the Tribus Cairinini in the Subfamily Anatinae. The two goose species, Domestic Goose (Anser anser var. domestica) and Red-breasted Goose (Rufibrenta ruficolli) from the Subfamily Anserinae, finally yielded the weakest bands. However, in all cases a clear signal was found by WB confirming the specificity and demonstrating the broad cross reactivity within the order of Anseriformes (Table1).

In order to test the possibility of using mab $14 \mathrm{~A} 3$ in immunoassays, we further analysed whether the monoclonal antibody could facilitate the detection of substrate bound antibodies from geese and Muscovy ducks. Therefore, using mab 14A3 as secondary antibody, an indirect IF-test was conducted with sera of APMV-1 positive domestic geese and Muscovy ducks. A representative result is shown in Figure 2. In APMV-1 infected cell-cultures, clear foci of typical cytopathic effects with formation of giant cells were visible, represented by cytoplasmic fluorescence and mottled appearance of the cells. In addition, the nuclei of some elongated cells also showed a bright fluorescence. These foci of alteration were surrounded by uninfected cells that did not show any staining. In uninfected controls no signal was observed (data not shown).

We next analysed the applicability of mab $14 \mathrm{~A} 3$ as secondary antibody in an indirect ELISA system. Selected APMV-1 positive sera from domestic geese and Muscovy ducks taken at 
specific time points after immunisation with an inactivated APMV-1 vaccine were titrated within this test-system. As shown in Figure 3A for one individual goose (serum dilutions are given as $\log _{2}$ (dilution $x$ 50)), serum taken at the day of immunisation yields very little reactivity. At a serum dilution of 1:50 (=0), the optical density did not surmount a value of 0,2 and background noise is negligible from a dilution of 1:200 $(=2)$ on. However, three weeks post vaccination a clear seroconversion became evident by increased reactivity (OD of 1.557 at a dilution of 1:50). This clear reactivity is also detectable with sera taken at the two subsequent time points tested. At higher serum dilutions reactivity declined. For sera obtained three, seven and ten weeks after immunisation, reactivity remains above that of the sera taken prior to immunisation up to a dilution of 1:6400 (=7), 1:1600 (=5) and 1:25600 (=9) respectively. Comparable results were obtained for four other birds tested by ELISA-titration. Comparing the results of the ELISA-titration with serum-titres measured by the conventional HI test, a parallel development in the titre-course could be demonstrated (Figure 3B). Like the ELISA test, the HI test revealed a distinct seroconversion three weeks after immunisation. All samples taken at that time point had an $\mathrm{HI}$ titre of $32\left(\log _{2}=5\right)$ or greater. The ELISA titres were predominantly 10 - to_100-fold higher, being $400\left(\log _{2}=8,64\right)$ or greater. In nearly all birds tested, a second or further titre rise was detectable in both tests ten weeks post vaccination. At that time point highest $\log _{2}$ titres were reached (HI 8 to 10 , ELISA $10_{8} 64$ to $1564)$.

The specificity of sero-reactivity to APMV-1 was confirmed by WB analysis. Sera taken at the day of vaccination produced no APMV-specific reaction on the radiography (Figure 4). In agreement with the ELISA data, three weeks post vaccination strong reactivity with APMVproteins and in particular with the comigrating phosphoprotein $(\mathrm{P})$, nucleoprotein $(\mathrm{NP})$ and fusion protein 1 (F1), was detectable. Moderate bands were visible at the position of the haemagglutinin-neuraminidase protein (HN), which was detected by the HI test. Seven weeks

\section{Deleted: ,}

Deleted: ,

Deleted:

Deleted: -

Deleted: -

Deleted: -

Deleted: -

Deleted: ,

Deleted: -

Deleted: ,

Deleted: -

Deleted: ,

Deleted: ,

Deleted: Specificity

Deleted: provoked

Deleted: hemagglutinin

Deleted: I-

Deleted: CAVP-2007-0150.R1

Deleted: CAVP20070150-3

Deleted: CAVP20070150 
post vaccination, reactivity in duck sera declined, whereas in goose sera the bands seemed to be more distinct. Both bird species showed highest reactivities ten weeks post vaccination. At that time point, especially in the goose, an additional band at the position of the matrix protein (M) was visible.

\section{Discussion}$$
4
$$

In this study we describe a monoclonal antibody with a specific reactivity to waterfowl IgY

and evaluate its applicability in a variety of serological assay systems to detect APMV1positive reactants.

Mab 14A3 had been characterized as a useful tool for flow cytometric analysis of lymphocyte subpopulations (Kothlow et al., 2005) and showed reactivity with serum from different waterfowl species. Here we complement this initial analysis by cross reactivity testing with a wider range of waterfowl species. The monoclonal antibody shows strong reactivity with the Ig light chain of swans (Subfamily Anserinae) and ducks of the Tribus Anatini (Subfamily Anatinae) and to a somewhat lesser extent with that of ducks of the Tribus Cairinini (Subfamily Anatinae) or geese (Subfamily Anserinae). The fact that antibodies to serum Igs of one bird species cross-react with sera from other avian species is not an uncommon phenomenon. Similar results were obtained in earlier studies. Baxendale et al. (1971) demonstrated that both rabbit anti-pigeon and rabbit anti-chicken serum react with serumproteins of common pheasants (Phasianus colchicus), domestic Mallards (Anas platyrhynchos var. domestica), domestic chickens (Gallus gallus var. domestica), turkeys (Meleagris gallopavo), domestic pigeons (Columba livia var. domestica) and house sparrows (Passer var. domesticus). Cromie et al. (1993) observed cross-relativities between a polyclonal antiduck antibody and serum of feral Barnacle geese (Branta leucopsis). Baghian et al..2 (1999)
Deleted: reactivies

Deleted: 1

Deleted: becomes
Deleted: was previously

Deleted: 1

Deleted: Tew Roman, Not Highlight

Deleted: $d$

Formatted: Font: Times New

Deleted:

Deleted: reactivities

Deleted: CAVP-2007-0150.R1

Deleted: CAVP20070150-3

Deleted: CAVP20070150 
reported a broad cross reactivity of an anti-cockatiel IgY hyperimmune serum in the AGP, including several birds of the Order Psittaciformes. However, the results of our cross reactivity test differ from the results of these studies by the fact that a monoclonal antibody, directed against specific epitopes of the IgY molecule was used. Taking this fact into consideration the degree of cross reactivity is even more notable and confirms the close Deleted: ice phylogenetic relationship among the Anseriformes.

Concerning the observation of different strength in the reaction of mab $14 \mathrm{~A} 3$ it is tempting to speculate that the degree of cross reactivity correlates with phylogenetic pt Deleted: relationships within the order Anatiformes, Family Anatidae (Table 1). However, as the sera were not normalised with respect to their Ig content, it seems more plausible that the differences in the degree of reactivity are due to variable concentrations of Igs in the serum of the individual birds. Importantly, the results of this study show clearly that the observed differences in the strength of reactivity do not affect the discrimination of positive and Deleted: clearly Deleted: Deleted: negative sera within different serological test systems.

The results of IF-test, ELISA and WB analysis prove the function of the mab 14A3 as part of Deleted: an antibody cascade. The monoclonal antibody detects serum Igs in their native conformation and binds to substrate bound antibodies. In the IF-test, the ELISA and the WB, it is therefore able to mediate, as secondary antibody, the binding between virus specific antibodies and a tertiary FITC- or POD-conjugated antibody. The specificity of the reaction in the IF-test is verified by the fact that foci of infected cells are clearly distinguishable from surrounding uninfected cells or from cells in uninfected control-cups respectively. As known for paramyxoviruses, antigen seems to be present predominantly in the cytoplasm, but can also appear in some of the nuclei, described as intranuclear inclusion bodies by Granzow et al. Deleted: , (1999). 
Like the ELISA, the WB also correlated well with the HI test, concerning the differentiation between positive and negative sera. Remarkably, by WB analysis, only low reactivity towards the $\mathrm{HN}$ protein was observed, despite $\mathrm{HN}$-specific antibodies measured in high titres by the HI test. It was shown by Crennell et al. (2000) and Connaris et al. (2002) in crystallographic studies that the three dimensional structure of the globular head of the HN-glycoprotein forms specific receptor binding sites. Whereas in the $\mathrm{HI}$ test $\mathrm{HN}$ proteins are present as native epitopes, they show predominantly a linear structure in the WB under denaturing conditions. The lack of reactivity in the WB, in contrast to the corresponding high HI titres, indicates that the immune reaction to the $\mathrm{HI}$-active part of the $\mathrm{HN}$ protein is directed predominantly against conformational dependent epitopes. This is corroborated by the observations of Iorio et al. (1983) that monoclonal antibodies, directed against the HN protein, only bind to $\mathrm{HN}$ in nitrocellulose transfers of sodium dodecyl sulphate gels, if it has been neither reduced nor boiled.

A logical consequence is that differentiation between APMV-serotypes is only possible in the HI test, whereas WB and ELISA are only capable to detect APMV-positive sera. Applying mab 14A3 in routine immunoassays, the indirect ELISA would be the method of choice in the screening of sera for APMV-specific antibodies. By WB-analysis virus specific reaction can be verified. This is valuable, considering the high nonspecific reactivity often observed in sera of lower quality, is a frequent problem concerning field sera from wild birds.

Of further importance is the fact that mab 14A3 can be employed in the detection of infections with other viral agents, for example avian influenza viruses. As waterfowl represents a potential reservoir for orthomyxoviruses, monitoring of wild aquatic birds can be of great importance. Detection of antibodies against AIV indicates, also at time points where no virus shedding occurs, that the bird has been in contact with the infectious agent. In addition, the problem of interference with antibodies produced subsequently to vaccination,

\section{Deleted: -}

Deleted: Remarkable

Deleted: was that

Deleted: -

Deleted: -

Deleted: -

Deleted: is

Deleted: ,

Deleted: ,

Deleted: -

Deleted: -

Deleted: -

Deleted: -

Deleted: depending

Deleted: ,

Deleted: -

Formatted: Indent: First line: 35.4 pt

Deleted: -

Formatted: Font: Times New Roman, Not Highlight

Deleted: un

Formatted: Font: Times New

Deleted: Matter of

Formatted: Font: Times New

Roman, Not Highlight

Formatted: Indent: Before: $0 \mathrm{pt}$, First line: $35.4 \mathrm{pt}$

Deleted: Of current

Deleted: further on

Formatted: Font: Times New

Deleted: the

Deleted: e

Deleted: CAVP-2007-0150.R1

Deleted: CAVP20070150-3

Deleted: CAVP20070150 
known from domestic poultry, doesn't exist in wild birds. Therefore suitable serological tests such as an ELISA for waterfowl can help to determine the AIV infection rate in these birds, offering the possibility of a systematic surveillance in relevant areas and an evaluation of the resulting infection pressure on more susceptible poultry species.

Deleted: $\mathbb{\text { II }}$

II

II

II

Deleted: II 
Baxendale, W., Courtenay, J.S., Phillips, A.W. \& Zola, H. (1971). Some properties of pigeon and other avian serum proteins. The International Journal of Biochemistry, 2, 419-422.

Baghian, A., Reyes, C.V., Mendoza, A., Tully, T. \& Kousoulas, K.G. (1999). Production of a Rabbit Anti-Cockatiel Immunglobulin G and Characterisation of its Cross-Reactivities with Immunglobulin $\mathrm{G}$ of other Psittacine Species.

Avian Diseases, 43, 48-54.

Bernius, E. (1997). Serologische Untersuchungen zum Vorkommen virusbedingter Infektionen und Krankheiten bei Hausgänsen aus Norddeutschland. Dissertation, Justus-^ Liebig-Universität Gießen.

Campitelli, L., Mogavero, E., De Marco, M.A., Delogu, M., Puzelli, S., Frezza, F., Facchini, M., Chiapponi, C., Foni, E., Cordioli, P., Webby, R., Barigazzi, G., Webster, R.G. \& Donatelli, I. (2004). Interspecies transmission of an H7N3 influenza virus from wild birds to intensively reared domestic poultry in Italy.

Virology, 20, 24-36.

Connaris, H., Takimoto, T., Russell, R., Crennell, S., Moustafa, I., Portner, A. \& Taylor, G. (2002). Probing the sialic acid binding site of the haemagglutinin-neuraminidase of Newcastle disease virus: identification of key amino acids involved in cell binding, catalysis, and fusion. Journal of Virology, 76, 1816-1824.

Crennell, S., Takimoto, T., Portner, A. \& Taylor, G. (2000). Crystal structure of the multifunctional paramyxovirus haemagglutinin-neuraminidase. Nature Structural Biology, 7, 1068-1074.

Cromie, R.L., Brown, M.J., Forbes, N.A., Morgan, J. \& Stanford, J.L. (1993). A comparison and evaluation of techniques for diagnosis of avian tuberculosis in wildfowl. Avian Pathology, 22, 617-630.

Granzow, H., Weiland, F., Mundt, E., Köllner, B. \& Werner, O. (1999). Intranuclear inclusions in cells infected with Newcastle disease virus. Journal of Veterinary Medicine. B, 46, 411-421.

Hess, J.C. \& Paré, J.A. (2004). Viruses of Waterfowl. Seminars in Avian and Exotic Pet Medicine, 13, 176-183.

Iorio, R.M. \& Bratt, M.A. (1983). Monoclonal antibodies to Newcastle disease virus: delineation of four epitopes on the $\mathrm{HN}$ glycoprotein. Journal of Virology, 48, 440-450.

Kothlow, S., Mannes, N.K., Schaerer, B., Rebeski, D.E., Kaspers, B. \& Schultz, U. (2005). Characterization of duck leucocytes by monoclonal antibodies. Developmental and Comparative Immunology, 29, 733-748.

Laemmli, U.K. (1970). Cleavage of structural proteins during the assembly of the head of bacteriophage T4. Nature, 227, 680-685.

Marquardt, W.W., Johnson, R.B., Odenwald, W.B. \& Schlotthober, B.A. (1980). An indirect enzyme-linked immunosorbent assay (ELISA) for measuring antibodies in chickens infected with infectious bursal disease virus. Avian Diseases, 24, 375-385.

Mayr, A., Bachmann, P.A., Bibrack, B. \& Wittmann, G. (1974). Virologische Arbeitsmethoden, Band I (A

Murphy, F.A., Gibbs, E.P.J., Horzinek, M.C. \& Studdert, M.J. (1999). Laboratory Diagnosis of Viral Diseases. In Veterinary Virology, 3rd edn, AP (pp. 193-223),

O'Beirne, A.J. \& Sever, J.L. (1992). Enzyme Immunoassay. In S. Specter \& G. Lancz (Eds.), Clinical Virology Manual, 2nd edn (pp. 153-170). Elsevier-Verlag.

Office International des Epizooties (2004). Newcastle Disease. In Manual of Diagnostic Tests and Vaccines for Terrestrial Animals (chapter 2.1.15) 5 th edn, vol.1, OIE, Paris, 270$\underline{282}$
Deleted: II

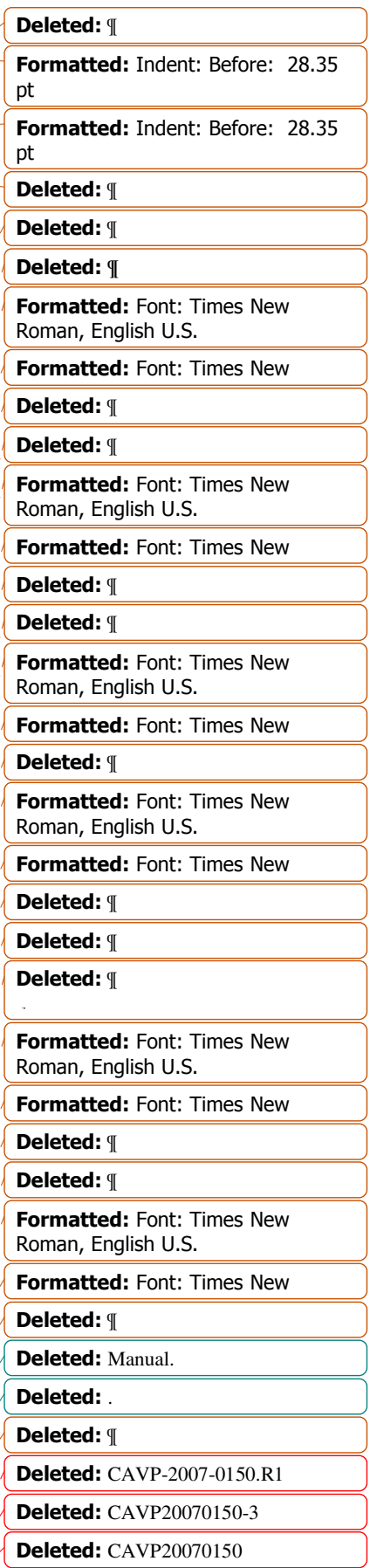


Reed, K.D., Meece J.K., Henkel, J.S. \& Shukla, S.K. (2003). Birds, Migration and Emerging Zoonoses : West Nile Virus, Lyme Disease, Influenza A and Enteropathogens. Clinical Medicine \& Research, 1, 5-12.

Refsum, T., Handeland, K., Baggesen, D.L., Holstad, G. \& Kapperud, G. (2002). Salmonellae in Avian Wildlife in Norway from 1969 to 2000. Applied and Environmental Microbiology, 68, 5595-5599.

Slaght, S.S., Yang, T.J., van der Heide, L. \& Fredrickson, T.N. (1978). An enzyme-linked immunosorbent assay (ELISA) for detecting chicken anti-reovirus antibody at high sensitivity. Avian Diseases, 22, 802-805.

Takakuwa, H., Ito, T., Takada, A., Okazaki, K. \& Kida, H. (1998). Potentially virulent Newcastle disease viruses are maintained in migratory waterfowl populations. Japanese Journal of Veterinary Research, 45, 207-215.

Wolters, H.E. (1982). Die Vogelarten der Erde. Hamburg, Berlin:Paul Parey.
Deleted: $\mathscr{I}$

Deleted: II

Deleted: $\mathbb{I I}$

Deleted: II

Deleted:

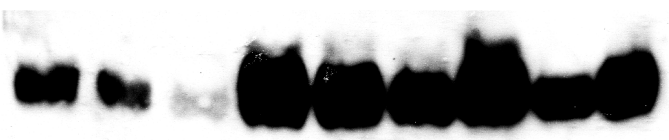

Aad $\mathrm{Rr}$ Ggd Co $\mathrm{Sm} \mathrm{Cm}$ Ap As Da
Figure 1. Cross reactivity of mab $14 A 3$ with the light chain of IgG from different waterfowl species. Sera from eight different waterfowl species and a chicken were separated by $10 \%$ SDS-PAGE, transferred to nitrocellulose and probed by mab $14 \bar{A} 3$ in Western blot analysis. Reactivity is shown after exposure of 3 minutes. Species tested included: Aad = Domestic Goose (Anser anser var. domestica); $R r=$ Red-breasted Goose (Rufibrenta ruficollis); Ggd = Domestic Chicken (Gallus gallus var. domestica); Co = Mute Swan (Cygnus olor); Sm = Black-necked Swan (Sthenelides melanocoryphus); $\mathrm{Cm}=$ Muscovy Duck (Cairina moschata), Ap $=$ Mallard (Anas platyrhynchos); As = White-winged Wood Duck (Asarcornis scutulatus); $\mathrm{D} a=$ Common Pintail (Dafila acuta).

\section{Formatted}

Deleted: -

Formatted: Font: Times New Roman, Italic

Deleted: on a...western

Formatted [3]

Deleted: CAVP-2007-0150.R1

Deleted: CAVP20070150-3

Deleted: CAVP20070150 


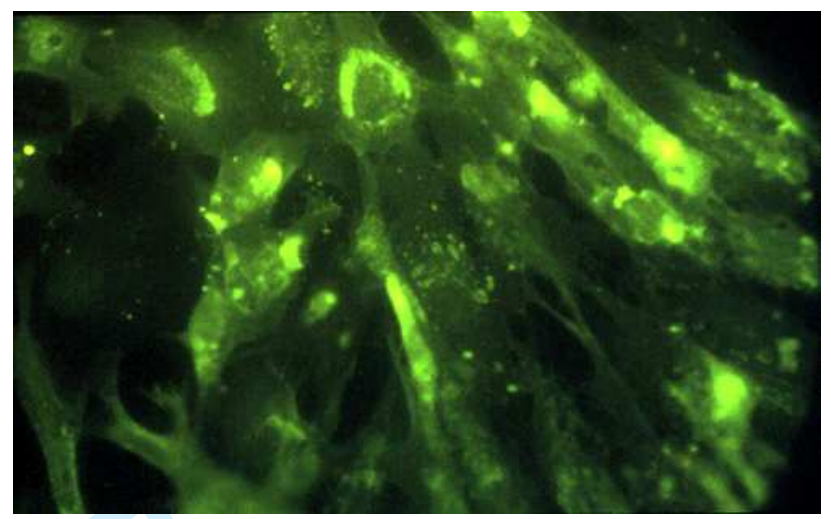

Figure 2. Suitability of mab $14 A 3$ to facilitate the detection of substrate bound antibodies in the indirect immunofluorescence test. APMV-I-infected primary chicken embryo liver cells were incubated with an APMV-1 seropositive goose serum. Subsequently mab 14A3 was added, followed by the visualisation of antigen-antibody-complexes using FITC-conjugated goat-antimouse-IgG antibodies and a fluorescence microscope (100 fold magnification).

Deleted: 1

II

Formatted: Font: Times New

Formatted: Font: Times New Roman, Not Bold, Italic

Formatted: Font: Times New Roman, Italic

Deleted: 1

Formatted: Font: Times New

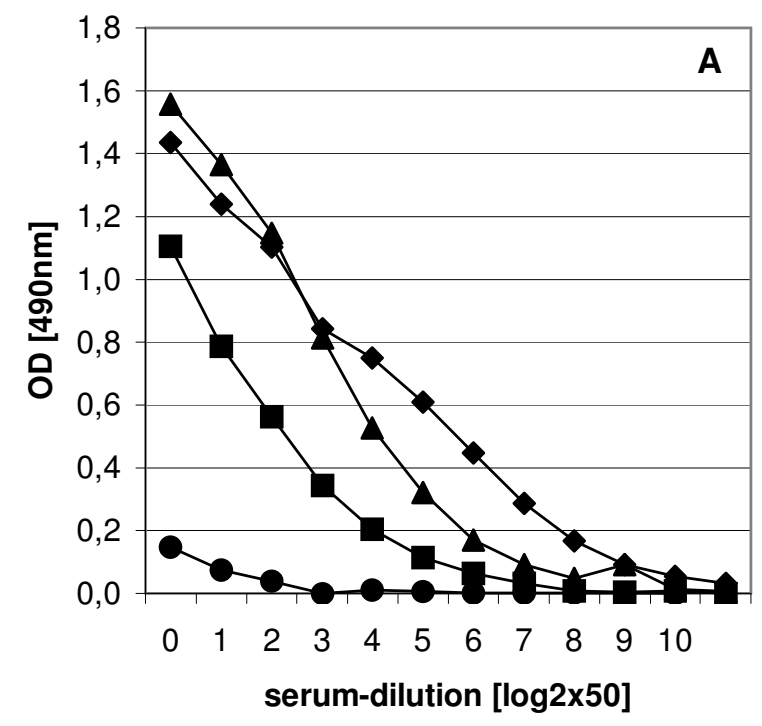

Deleted: CAVP-2007-0150.R1

Deleted: CAVP20070150-3

Deleted: CAVP20070150 

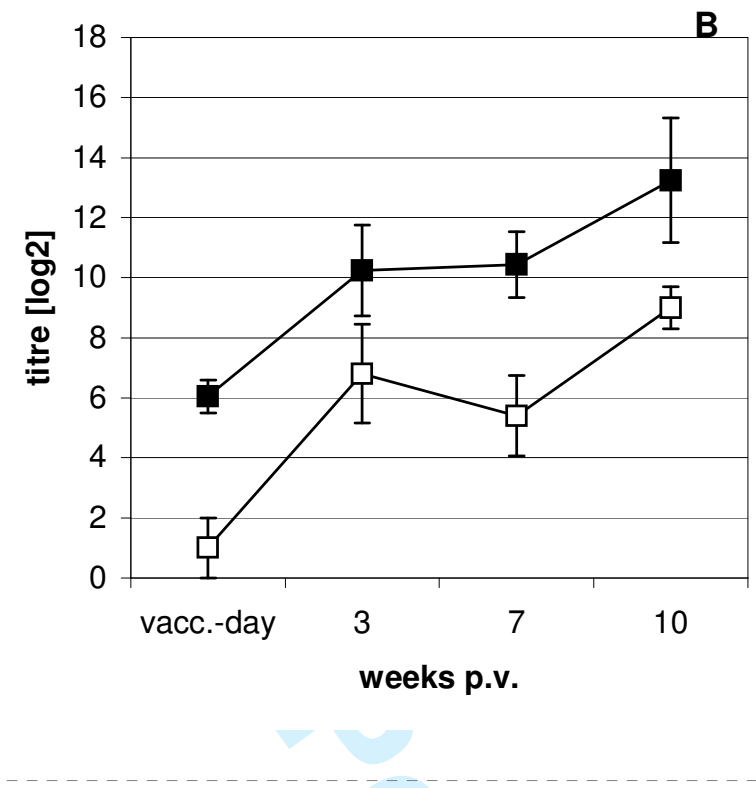

Figure 3. APMV-1 ELISA using mab 1443 as secondary antibody.

Sera from domestic geese and Muscovy ducks, taken at different time points after immunisation with an APMV-1 vaccine, were tested by ELISA. Shown is (A) the reactivity of sera from one representative goose with respect to different serum dilutions, expressed as the logarithm of serial twofold dilutions starting at a dilution of 1:50 (day of immunisation $\bullet$, $3 \mathbf{\Delta}$, 7 and $10-$ weeks thereafter) and $(B)$ the comparison of the reactivity of sera from three geese and two ducks, in ELISA (filled symbols $\square$ ) and HI-test (empty symbols $\square$ ), expressed as the log2 of the average titres with corresponding standard deviations.

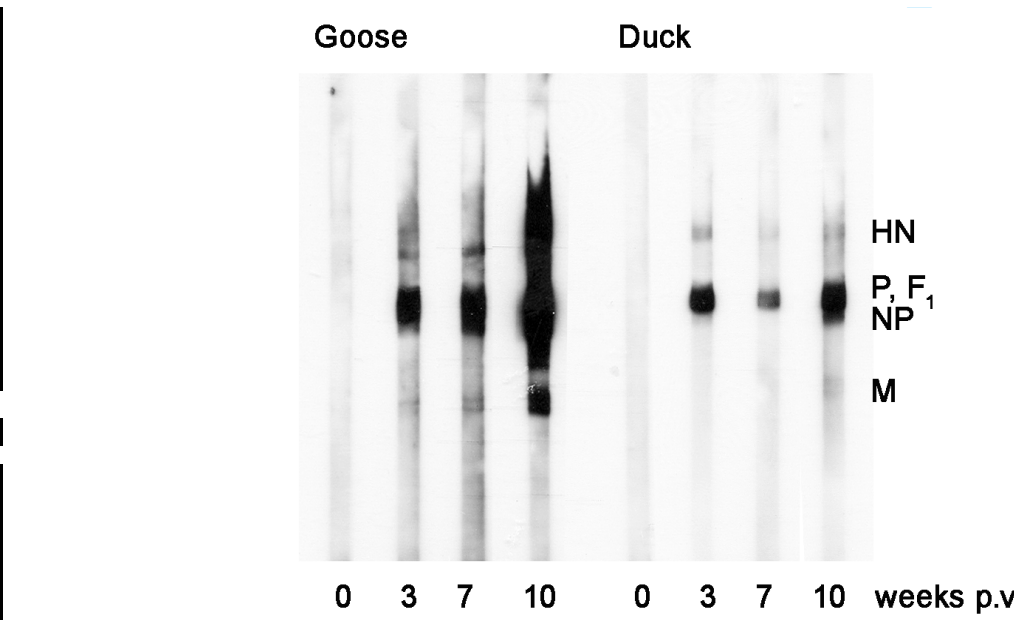

Figure 4. APMV-1 specific reactivity of goose and duck sera, confirmed by Western blot. Testsera from domestic geese and Muscovy ducks, collected at different time points after immunisation with an APMV-1 vaccine, were tested for their reactivity to APMV-1 proteins. Mab $14 A 3$ served as secondary antibody. Reactivity is shown after an exposure time of 10 seconds. $\left(H N=\right.$ haemagglutinin-neuraminidase, $P=$ phoshoprotein, $N P=$ nucleoprotein, $F_{1}=$ fusion protein $1, M=$ matrix protein).

Formatted: Font: Times New

Formatted: Font: Times New Roman, Not Bold, Italic

Formatted: Font: Times New Roman, Italic

Formatted: Font: Times New Roman, Not Bold, Italic

Formatted: Font: Times New Roman, Italic

Formatted: Font: Times New Roman, Not Bold, Italic

Formatted: Font: Times New Roman, Italic

Deleted: $\mathbb{I}$

II

Formatted: Font: Times New

Formatted: Font: Times New Roman, Not Bold, Italic

Formatted: Font: Times New Roman, Italic

Deleted: $d$

Deleted: CAVP-2007-0150.R1

Deleted: CAVP20070150-3

Deleted: CAVP20070150

Formatted: Font: Times New

Formatted: Font: Times New Roman, Italic

Formatted: Font: Times New 
Table 1. Phylogenetic tree of eight selected waterfowl species, which were used to test the cross-reactivity of mâb $1 \overline{4} A 3$ (Wotters 1982 ).

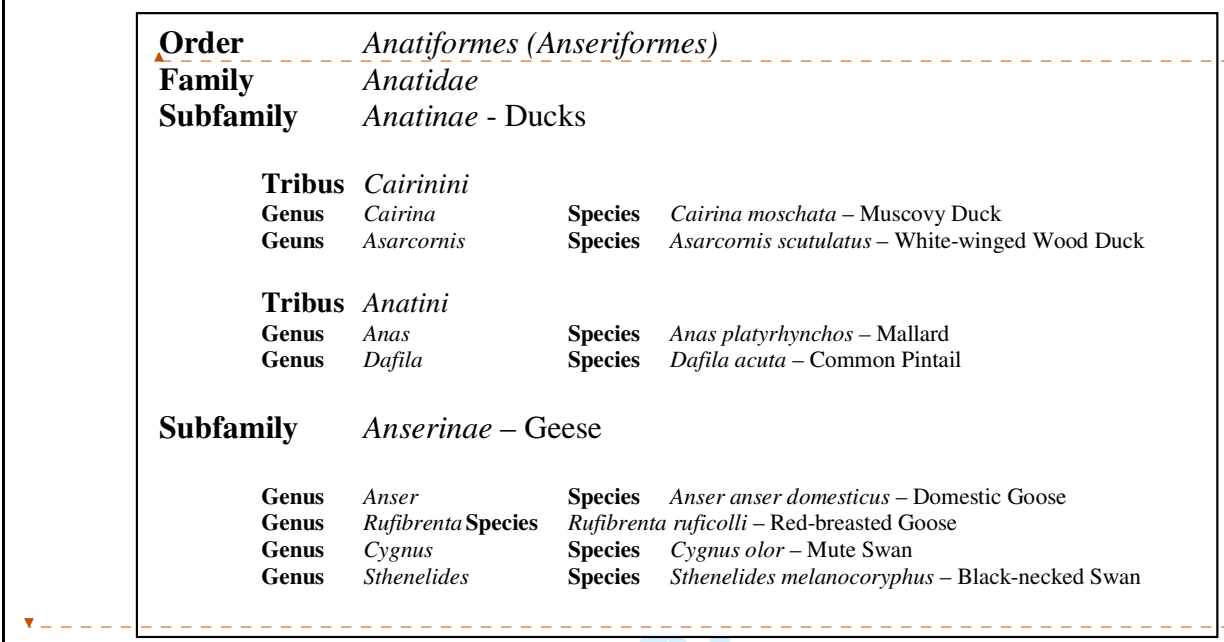

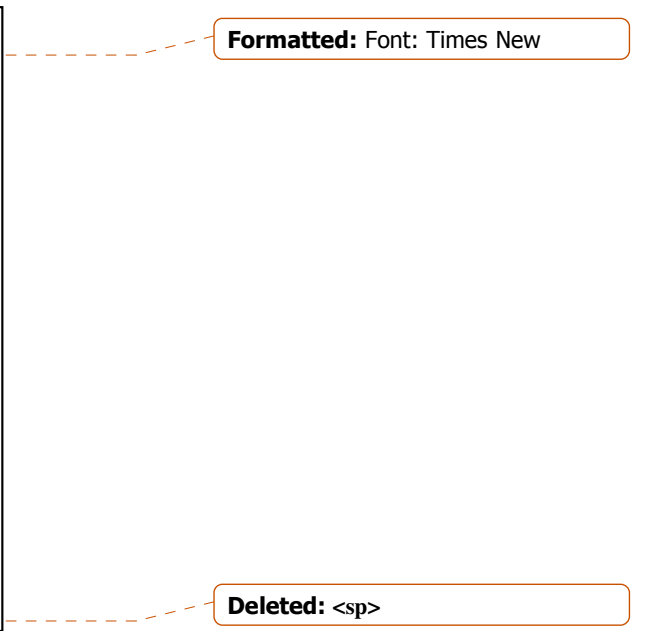

Deleted: $<$ sp $>$
Formatted: Font: Times New

Formatted: Font: Times New Roman, Italic

Deleted: <sp>

Deleted: Hans E.

Deleted: "Die Vogelarten der Erde", Paul Parey

Formatted: Font: Times New 
Page 15: [1] Formatted Verity 3/12/2008 3:34:00 PM

Font: Times New Roman, English U.S.

Page 15: [1] Formatted

Font: Times New Roman

\section{Verity}

3/12/2008 3:04:00 PM Verity 3/12/2008 3:35:00 PM

Font: Times New Roman

Page 15: [2] Formatted Verity

3/12/2008 3:35:00 PM

Font: Times New Roman, Not Bold, Italic

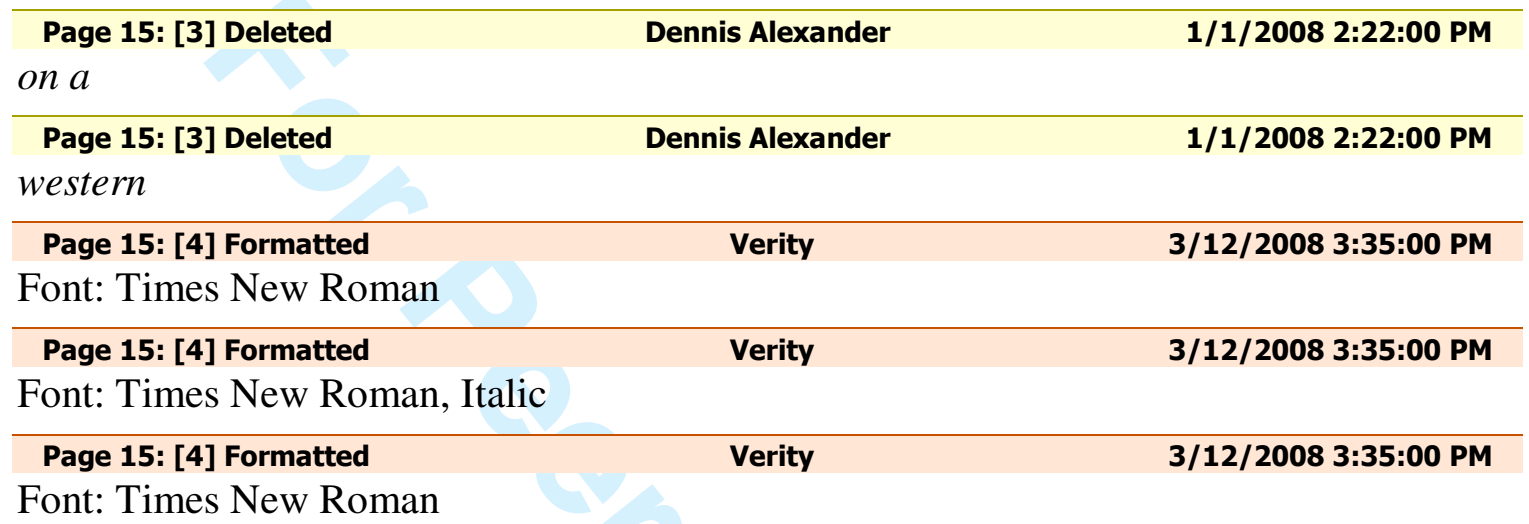

\section{Page 15: [4] Formatted} Verity 3/12/2008 3:35:00 PM

Font: Times New Roman, Italic

Page 15: [4] Formatted

Font: Times New Roman

$$
\text { Page 15: [4] Formatted }
$$

Font: Times New Roman, Italic

Page 15: [4] Formatted Verity

\section{Verity}

Verity

3/12/2008 3:35:00 PM

Font: Times New Roman
3/12/2008 3:35:00 PM

3/12/2008 3:35:00 PM
Verity

3/12/2008 3:35:00 PM

Font: Times New Roman, Italic
Page 15: [4] Formatted

Font: Times New Roman

\section{Verity}

3/12/2008 3:35:00 PM

Page 15: [4] Formatted

Font: Times New Roman, Italic

\section{Verity}

3/12/2008 3:35:00 PM

\section{Page 15: [4] Formatted}

Font: Times New Roman

Page 15: [4] Formatted

Font: Times New Roman, Italic

\section{Verity}

3/12/2008 3:35:00 PM

Verity

3/12/2008 3:35:00 PM
Page 15: [4] Formatted Font: Times New Roman

\section{Page 15: [4] Formatted}

Font: Times New Roman, Italic
Verity

3/12/2008 3:35:00 PM
Verity

3/12/2008 3:35:00 PM

\section{Page 15: [4] Formatted}

Font: Times New Roman 
Page 15: [4] Formatted

Font: Times New Roman, Italic
Verity

3/12/2008 3:35:00 PM

Page 15: [4] Formatted

Font: Times New Roman

Verity

3/12/2008 3:35:00 PM
Page 15: [4] Formatted

Font: Times New Roman, Italic

Verity

3/12/2008 3:35:00 PM

Page 15: [4] Formatted

Font: Times New Roman

Verity

3/12/2008 3:35:00 PM
Page 15: [4] Formatted

Font: Times New Roman, Italic

Verity

3/12/2008 3:35:00 PM
Page 15: [4] Formatted

Font: Times New Roman

Page 15: [4] Formatted

Font: Times New Roman, Italic

Page 15: [4] Formatted

Font: Times New Roman

Page 15: [4] Formatted

Font: Times New Roman, Italic

Verity

3/12/2008 3:35:00 PM

Verity

3/12/2008 3:35:00 PM

Verity

3/12/2008 3:35:00 PM

Verity

3/12/2008 3:35:00 PM
Page 15: [4] Formatted

Verity

3/12/2008 3:35:00 PM

Font: Times New Roman

Page 15: [4] Formatted

Verity

3/12/2008 3:35:00 PM

Font: Times New Roman, Italic

Page 15: [4] Formatted

Verity

3/12/2008 3:35:00 PM

Font: Times New Roman

Verity

3/12/2008 3:35:00 PM

Font: Times New Roman, Italic

Page 15: [4] Formatted

Verity

3/12/2008 3:35:00 PM

Font: Times New Roman

Page 15: [4] Formatted

Verity

3/12/2008 3:35:00 PM

Font: Times New Roman, Italic

\begin{tabular}{lll}
\hline Page 15: [4] Formatted & 3erity & 3/12/2008 3:35:00 PM
\end{tabular}

Font: Times New Roman

$\begin{array}{lll}\text { Page 15: [4] Formatted } & \text { 3erity } & \text { 3/12/2008 3:35:00 PM }\end{array}$

Font: Times New Roman, Italic

$\begin{array}{lll}\text { Page 15: [4] Formatted } & \text { 3/12/2008 3:35:00 PM }\end{array}$

Font: Times New Roman

Page 15: [4] Formatted

Verity

3/12/2008 3:35:00 PM

Font: Times New Roman, Italic

Page 15: [4] Formatted

Verity

3/12/2008 3:35:00 PM

Font: Times New Roman

Page 15: [4] Formatted

Verity

3/12/2008 3:35:00 PM

Font: Times New Roman, Italic 
Page 15: [4] Formatted Verity 3/12/2008 3:35:00 PM

Font: Times New Roman 